\title{
Kidney Large Cell Neuroendocrine
}

\section{Carcinoma}

National Cancer Institute

\section{Source}

National Cancer Institute. Kidney Large Cell Neuroendocrine Carcinoma. NCI Thesaurus.

Code C159225.

An aggressive, high-grade and poorly differentiated carcinoma with neuroendocrine

differentiation that arises from the kidney. It is characterized by the presence of malignant large cells. 